\title{
FOR THE NEXT GENERATION
}

\section{Dutch Protestant church commemorations in North America, I960-1980*}

\begin{abstract}
For the next generation: Dutch Protestant church commemorations in North America, I960-1980

In this article I describe congregational commemorations of Dutch immigrants and descendants living in the United States and Canada in the 196os and 1970s. I propose that these commemorations served to pass on the faith and migration stories to the next generation. The concern of the writers of the commemorative books reflects this desire and less an effort to faithfully retell the story of the congregation. By looking at congregations on both sides of the border with clear differences in setting and developments, it provides a way to understand the commonalities of the denominations as ethno-religious communities as well as see the diversity across the border.
\end{abstract}

'We desire that the faith of future generations be strengthened through the recollection of their forebears', Rev. Simon Viss, Houston, B.C. I964 ${ }^{\mathrm{I}}$

As the official periodical of the Christian Reformed Church, The Banner played an important role in setting the tone and direction within the denomination in North America. Covers usually included photos or artwork of denominational activities so when a photo of burning wooden shoes appeared on the cover of The Banner of 3 November I980, it must have shocked most of the magazine's subscribers. Membership in the Christian Reformed Church included many immigrants from the Netherlands as well as many more who

This research was made possible by a Visiting Research Fellowship from the Van Raalte Institute, Hope College, Holland, Michigan. I would like to thank Nora Faires for reading an earlier draft of this article as well as Hubert Krygsman for many discussions about the Dutch in Canada.

I. '25th Anniversary', Houston Christian Reformed Church, Houston, British Columbia (I964). Available at Heritage Hall, Calvin College, Grand Rapids, Michigan (Hereafter Heritage Hall). 


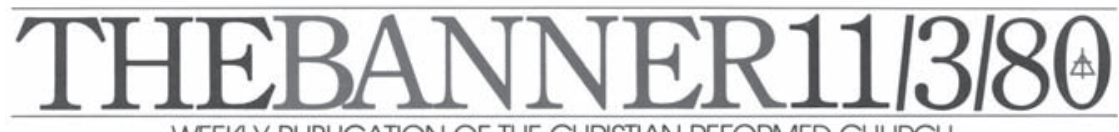

WEEKLY PUBLICATION OF THE CHRISTIAN REFORMED CHURCH

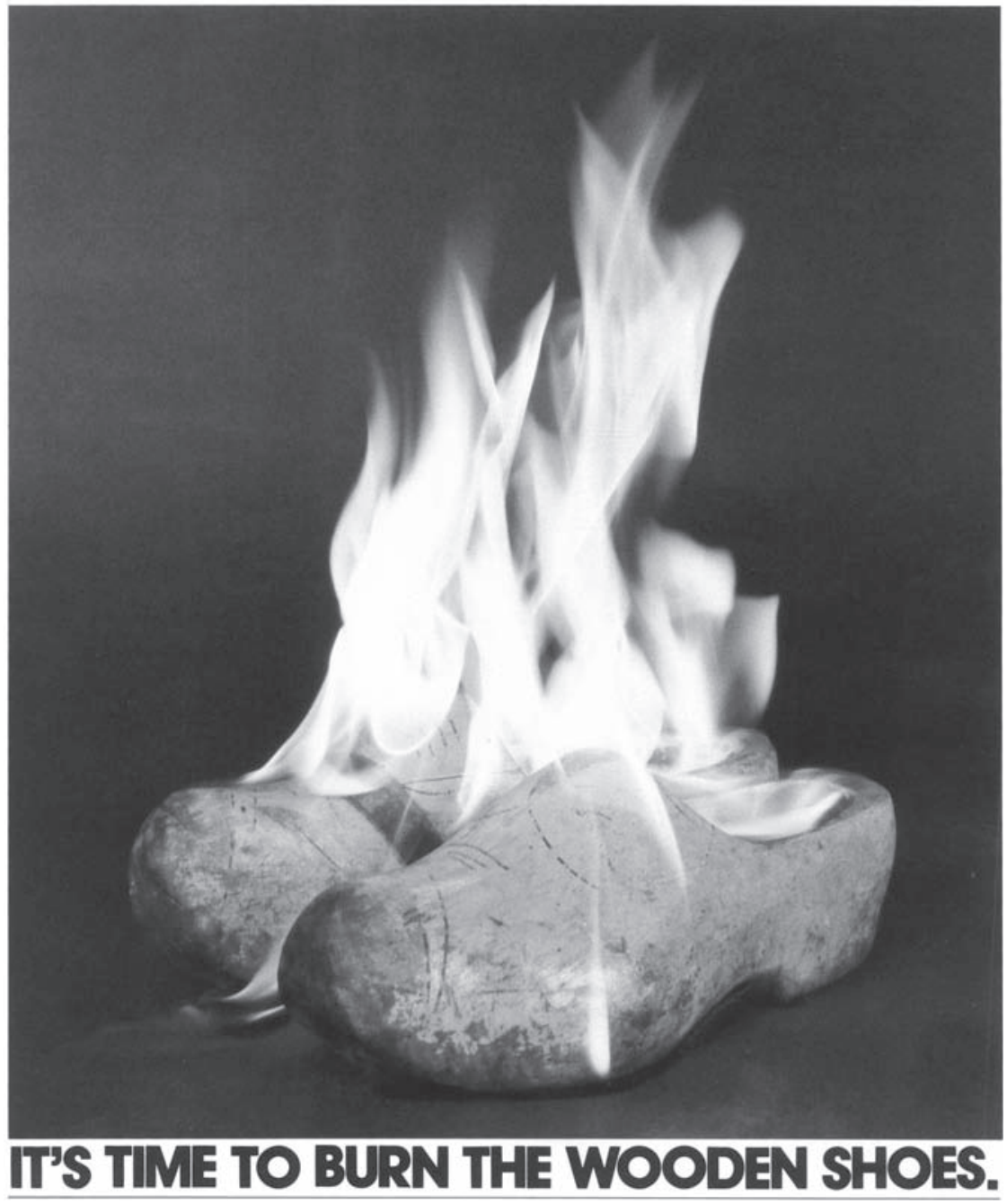

Ill. 1 Front page of the Banner, the weekly publication of the Christian Reformed Church, 3 November 1980, urging the community to sever its ties with its Dutch heritage. Source: private collection of the author. Used with permission. Cover photograph by Curtis Door.

traced their ancestors to the Netherlands. With the caption 'It's Time to Burn the Wooden Shoes', the entire issue challenged its members to rethink their denomination's ethnic identity. Editor Rev. Andrew Kuyvenhoven, himself an immigrant from the Netherlands, encouraged his readers to think of the denomination no longer as an 'ethnic' church because of the growing number of non-Dutch within the congregations of the denomination such as Korean 
immigrants and Native American converts. He acknowledged the importance of the church as an institution for immigrants because 'the church does not merely proclaim the only comfort; the church itself is the haven of comfort' but wanted the congregations and individuals within the denomination to move past their immigrant heritage. ${ }^{2}$

Even if readers acknowledged the theological merits of Kuyvenhoven's proposal, it ran counter to the cultural identity of many of his readers. Many within the Christian Reformed Church denomination and its constituent congregations had constructed a cultural identity shaped by migration from the Netherlands. Following the Second World War, congregations within the Christian Reformed Church, the Reformed Church in America, and the Protestant Reformed Church held the loyalty of many Dutch immigrants and their descendants. In I960, the Christian Reformed Church had 236,000 members and the particular synods of the Reformed Church in America in the west had i68,000.3 The institutional growth and success came from both natural increase and Dutch protestant immigrants who joined these denominations in the I950s. In the case of the Christian Reformed Church, the number of new congregations that formed in Canada between I945 and ig60 was II9 with a total membership over 53,000 by I960.4 While not all members traced their cultural identity to the Netherlands, the overriding tone of 'Dutchness' pervaded these denominations.

At the same time, the I960s and I970s brought new challenges to these immigrant congregations after the growth and prosperity of the I950s. If, according to James Bratt, the I950s saw a 'settling down into the nation' for those who claimed a Dutch ethnicity, 5 the I960s and I970s required convincing the next generation to remain loyal to the institutions started by their immigrant forbearers. Broader cultural and political movement in both the United States and Canada pulled the ties that had bound the immigrant community together. Mass media, economic mobility, and secularisation all challenged the ethnic identity of the immigrant institutions.

The importance of churches for immigrants and the creation of an ethnic identity can hardly be overstated. Since congregations functioned as one of the key institutions for immigrants, then the way the congregation understood itself and the way it constructed an ethnic identity is key to under-

2. Andrew Kuyvenhoven, 'It's time to burn the wooden shoes', The Banner, 3 November I980, 7-8.

3. James D. Bratt, Dutch Calvinism in modern America: a history of a conservative subculture (Grand Rapids I984) 222-223. The center of Dutch immigrants from the nineteenth century and after within the Reformed Church in America was in the west and not the older colonial areas of New York and New Jersey.

4. 1960 Yearbook of the Christian Reformed Church (Grand Rapids I960) I2-44.

5. Bratt, Dutch Calvinism, I87. 
standing how immigrants and their descendants understood themselves. The competing demands on the congregation as a social institution and as a faith community can be seen in the way Dutch congregations in North America commemorated their past during the I960s and I970s. Commemorations provided one place where members interpreted their experience for themselves. These commemorations interpreted the experience of migration and institution building for the next generation. Congregational commemorations provide one place to understand how the older generation, whether first generation immigrants in Canada or third and fourth generation ethnics in the United States, constructed a story of faith, effort, and progress to tell the next generation the worth of continuing the local congregation and continue to use a Dutch Protestant ethno-religious identity to understand the North American world. The congregational producers of an ethnic identity relied on constructing a collective memory during the I960s and I970s in the hopes that the immigration congregations would retain their vitality.

The Dutch immigrant congregational commemorations used their past to help construct an ethno-religious identity built on their experience as migrants and as Calvinists. ${ }^{6}$ Their memory of leaving the Netherlands, whether in the nineteenth century or in the pillarised twentieth century, shaped their construction of an ethnic identity in North America. Their Calvinist ideas about their covenant relationship with God as a people called apart needed to be told over and over. They were Calvinists through a Dutch lens which set them apart from other Calvinists in the United States even as the Dutch language became less of an issue over time. In the i960s and I970s, as their faith became less distinctive through ecumenical movements and a general evangelical push, their Dutchness became an embarrassment as Kuyvenhoven made clear that it was time to burn the wooden shoes.

\section{Historiographical and theoretical issues}

Much of the research on Europeans arriving in and settling in the United States ends with the I920s when the number of migrants decreased substantially. Scholarship rarely examines the continuing story of the migrants and their descendants in North America through the rest of the twentieth century. Much of this research focuses on the place of immigrants in the history of the United States and the specific contours of particular immigrant groups. Much research on Dutch North Americans fits this pattern as well with most

6. The desire to construct an ethnic identity is clearly not only a North American phenomenon as Nonja Peters' contribution to this volume makes clear. 
studies ending at least by the I940s if not earlier, including the two contributions to this volume by Michael Douma and Robert Schoone-Jongen.7

A few scholars of Dutch Americans have ventured beyond the I920s and the main immigration period. James Bratt's Dutch Calvinism in modern America examined the history of Dutch Calvinist leaders and those who shaped the 'minds' within Dutch Reformed circles from the developments in the nineteenth century until the I970s. Bratt's main interest was in the battles over Americanisation within the intellectual elite as evidenced by their writings in church periodicals, such as The Banner. Bratt emphasised the roll of leaders and dealt less with the beliefs of the people in the pews. Another foray into the years since the Ig20s was in Robert Swierenga's in-depth study of Dutch migrants in Chicago. He extended this fine case study through the late twentieth century of a single geographic location. ${ }^{8}$ In a smaller study, Peter Ester interviewed post-World War I I immigrants living in Holland, Michigan and found that these immigrants cherished their formative years in this community. 9

More has been written covering Dutch immigrants to Canada since the I920s because of the large migration after i945. Herman Ganzevoort examined the Dutch experience in Canada from the nineteenth century through the I980 with a broad and synthetic overview. ${ }^{\text {IO }}$ Frans J. Schryer's extensive study of Dutch immigrants in Ontario covered many aspects of community life for both Reformed and Catholic immigrants following the large influx after the Second World War. ${ }^{\text {II }}$ K. Ishwaran looked at Dutch immigrants living in Holland Marsh, Ontario. ${ }^{22}$ A number of master's thesis and dissertations have also been written. Michael Fallon's 2000 dissertation examined why Orthodox Reformed set themselves apart to the extent that they did in

7. See: Henry Zwaanstra, Reformed thought and experience in a new world: a study of the Christian Reformed Church and its American environment, 1890-1918 (Kampen I973); Herbert J. Brinks (ed.), Dutch American voices: letters from the United States, 1850-1930 (Ithaca I995); Robert P. Swierenga, Faith and family: Dutch immigration and settlement in the Untied States, 1820-1920 (New York 2000); Suzanne M. Sinke, Dutch immigrant women in the United States, 1880-1920 (Urbana 2002); Hans Krabbendam, Freedom on the horizon: Dutch immigration to America, 1840-1940 (Grand Rapids 2009).

8. Robert P. Swierenga, Dutch Chicago: a history of the Hollanders in the windy city (Grand Rapids 2002).

9. Peter Ester, “It was very, very church". Recollections of older Dutch-Americans on growing up in Holland, Michigan', The Oral History Review 35:2 (2008) II7-I38.

Io. Herman Ganzevoort, A bittersweet land: the Dutch experience in Canada, 1890-1980 (Toronto I988).

II. Frans J. Schryer, The Netherlandic presence in Ontario: pillars, class and Dutch ethnicity (Waterloo I998).

I2. K. Ishwaran, Family, kinship and community: a study of Dutch Canadians, a developmental approach (Toronto I977). 
Canada after the Second World War. ${ }^{\mathrm{I3}}$ Another notable dissertation was by Brad Breems. He examined a Dutch-Calvinist community in British Columbia to better understand ethnicity. ${ }^{\mathrm{I}}$ Betsy Biemond-Boer has also examined the issue of Dutch immigrant identity in Canada in her book "Die Hollanders zijn gek". Identiteit en integratie van bevindelijk gereformeerden in Canada. ${ }^{15}$ However, little has been written comparing issues of Dutch immigration and ethnicity in the United States and Canada.

The importance of the local congregation for immigrants has been noted by a number of scholars for over forty years. Timothy Smith in I966 called the congregation 'the primary institution in American religion' and studying congregations of immigrations 'offers some important insights into the relationship of religion and ethnic community. ${ }^{16}$ In I964, Raymond Breton concluded that 'religious institutions have the greatest effect in keeping the immigrant's personal associations within the boundaries of the ethnic community. ${ }^{77}$ A recent volume edited by Richard Alba, Albert J. Raboteau and Josh DeWind explored the commonalities and differences between immigration and religion at the end of the nineteenth and beginning of the twentieth centuries. They argued that the services of religious congregations are undoubtedly the most regular and widely observed of the manifestations of immigrant and ethnic communities. We can think of no other institution that provides so frequently the sites and occasions for the members of these communities to come together, recognise each other, engage in a variety of communications and transactions, and give meaning, both transcendental and secular, to their experiences. ${ }^{\mathrm{I} 8}$

I3. Michael Fallon, People of the covenant: Dutch Reformed immigration into Canada after World War II (Doctoral Dissertation, The University of Guelph 2000).

I4. Bradly Breems, "I tell them we are a blessed people". An analysis of 'ethnicity' by way of a Canadian Dutch-Calvinist Community (Doctoral Dissertation, The University of British Columbia I99I). Other theses include: Aileen Van Ginkel, Ethnicity in the Reformed tradition: Dutch Calvinist immigrants in Canada, I946-1960 (Master's Thesis, University of Toronto I982); Harry J. Kits, World views and social involvement: a proposal for classification of Canadian Neo-Calvinist social involvement, I945-I960 (Master's Thesis, Institute for Christian Studies I988); Joanne G. van Dijk, Ethnic identity retention and social support: a comparative analysis of first-generation elderly Dutch-Canadian Catholics and Calvinists (Master's Thesis, University of Guelph I990).

I5. Betsy Biemond-Boer, "Die Hollanders zijn gek". Identiteit en integratie van bevindelijk gereformeerden in Canada (Amsterdam 2008).

I6. Timothy L. Smith, 'Religious denominations as ethnic communities: a regional case study', Church History 35:2 (I966) 207-226.

I7. Raymond Breton, 'Institutional completeness of ethnic communities and the personal relations of immigrants', The American Journal of Sociology 70:2 (1964) 193-205.

I8. Richard Alba, Albert J. Raboteau, and Josh DeWind (eds.), Immigration and religion in America: comparative and historical perspectives (New York 2009) 22. 
Congregations clearly played an important social role for immigrants. That social role as a religious institution reflects immigrants' identity. Marlou Schrover has argued immigrant organisations, such as congregations, 'create, express, and maintain a collective identity'. Further, Schrover posited that 'It is through organisations that others can address immigrants as a collective and, as such, organisations say something about demarcations within and between immigrant groups, and between immigrants and the host society. ${ }^{\mathrm{Ig}}$ The congregations of Dutch Protestant immigrants clearly fall within this description of immigrant organisations.

In addition to serving as a social institution, congregations also serve at the heart of a system of meaning. Alba, Raboteau and DeWind argued that religion as a meaning system 'furnished immigrant communities with symbolic interpretation of the experience of immigration, ritual reinforcement of identity, and the moral support of self-esteem'. ${ }^{20}$ This definition built on the work of Robert Orsi and others who became interested in the ways religion is lived out in the world. Orsi's examination focused on how Italian immigrants in Harlem understood themselves through the festa in honor of the Madonna of II5th Street. As he emphasized, 'immigration was as much a spiritual event even as it was a political and social response to particular historical conditions; the outward journeying was matched by a changing inner terrain. ${ }^{21}$ The congregations of Dutch Protestant immigrants emphasised their particular faith perspective as one of the key reasons for continuing as a congregation.

\section{Sources and methodological issues}

Ethnic identity formation in North America among Dutch protestant immigrants clearly had a religious foundation. Robert Swierenga has written that "economics explains the "why" of immigration but religion largely determines the "how" of immigration and its effects'. ${ }^{22}$ From founding congregations to uniting and dividing as denominations, the protestant Dutch immigrants exerted much energy to build and maintain their churches. This work involved building actual buildings, preparing ministers, and, I would argue,

I9. Marlou Schrover, "Whenever a dozen Germans meet ...' German organisations in the Netherlands in the nineteenth century', Journal of Ethnic and Migration Studies 32:5 (2006) 847-864.

20. Alba, Raboteau, DeWind (eds.), Immigration and religion, 3.

2I. See Robert Anthony Orsi, The Madonna of 115th street: faith and community in Italian Harlem, 1880-1950, 2nd ed. (New Haven 2002) I50; see also: David D. Hall (ed.), Lived religion in America: toward a history of practice (Princeton 1997).

22. Swierenga, Faith and family, I53. 
the cultural work of convincing each other of the necessity of this work. Telling the history of themselves was some of this important cultural work.

Histories of denominations and congregations played a role in uniting people around a common cause. Denominational histories, in particular, could unite people across large geographical areas. These official stories were the context for the more intimate congregational stories. Commemorations at the denominational level such as the Tercentenary Celebration of the RCA in I928 or the Centennial of the CRC in I957 constructed a common story. ${ }^{23}$ These national commemorations included a large amount of institutional organisation and effort to unify the denominations given their tendency to splinter. ${ }^{24}$ These national commemorations had tight reins on the story being told. ${ }^{25}$ However, when local congregations commemorated themselves, the story did not always fit the broader outlines of the story told by national leaders. Particular details obviously differed greatly from congregation to congregation, but also how the story would integrate the broader story of Dutch migration. Some would only start with the local story while others would start in the Netherlands. The commonalities and variations in the local stories demonstrate the unity and diversity within the Dutch ethnic congregations.

Congregational commemorations took place on significant anniversaries of the organising of the church, anywhere from ten to one-hundred years. Some of these correlated to the arrival of immigrants to an area since a church was often the first institution organised. They generally included special worship services with former members and pastors. Banquets and other meals usually were a time of more relaxed celebration. Finally, congregations celebrating their anniversary published commemorative books. Generally the consistory commissioned a committee to write a church history and put it in book form and to also include photos of former pastors and church buildings. Many of these books also incorporated messages from former pastors, photos of different groups within the church, lists of leaders, and by the I970s, many included a pictorial directory of the present church members.

While generalisation about Dutch ethnicity in North America can be made using individual congregational commemorations, important nuances and differences did exist. The largest difference lies between the commemorations in Canada and the United States. The Canadian churches within the Christian

23. Publication Section of the Centennial Committee, One hundred years in the new world: the story of the Christian Reformed Church from 1857-1957: its origin, growth and institutional activities; together with an account of the celebration of its anniversary in its centennial year (Grand Rapids 1957); Tercentenary Committee on Research and Publication (eds.), Tercentenary studies Reformed Church in America: a record of beginnings (New Brunswick I928).

24. The Protestant Reformed Churches in America split from the Christian Reformed Church in 1925 .

25. See: One hundred years in the new world. 
Reformed Church were started in the late I940s and early I950s with a new migration from the Netherlands. Migrants from the Netherlands also came to the United States during this period but joined existing ethnic institutions that had a much longer history. The ethnic identity constructed in the tumultuous I960s and I970s in the United States and Canada by Dutch migrants and their descendants reflects these changing times for ethnicity and the way one particular group dealt with it through the stories they told. If they were truly telling the stories for the next generation, as many acknowledged, what did these stories say about those who told them and their motivations?

The writers of church anniversary books in the I960s and I970s argued that the institutions were worth preserving and had a role to play even if they were less distinctively Dutch. The language shift had occurred, quickly in the case of Canadian churches and in some us churches only in the I950s after almost 90 years of using at least some Dutch language in their communal life, yet the Dutch ethnic church should be preserved. Examining multiple anniversary books within this period shows how ethnic identity continued to be constructed and used for institution building in a multicultural environment.

Thanks to the diligent work of archivists, many of these congregational commemoration books have been collected into central repositories. The Joint Archives of Holland at Hope College in Holland, Michigan has a large collection Reformed Church in America congregational commemorations. Heritage Hall at Calvin College in Grand Rapids, Michigan serves as a repository of Christian Reformed Church congregational records. For this article, I focused on the commemorations of congregations in the Christian Reformed Church because it had a significant number of congregations in Canada allowing for cross-border analysis. I examined congregational commemorations from a wide geographic distribution in Canada because there were fewer commemorations given the relatively short history of these congregations. I chose congregational commemorations in the United States with wide geographic distribution to match the wide geographic distribution of the Canadian congregations.

These anniversary books served as a durable memorial to the anniversary celebration. The general pattern of the books had been set prior to the I96os. Among nineteenth-century Dutch-Calvinist immigrants in the United States, these books first appeared around i9oo. The First Reformed Church of Muskegon, Michigan published a 'Souvenier Programma' in I9०9 on the occasion of their 'Halve-Eeuw Feest'. This small booklet, in Dutch, included photos of the church building, pastors who had served the congregation, and the 'kerkenraadsleden voor I909 en I9IO'. As would many other books, it included the order of service for the worship service commemorating the event. $^{26}$ The early books sometimes only had pictures of pastors and former

26. 'Souvenier Programma', First Reformed Church, Muskegon, Michigan (I909). Available at Heritage Hall. 
church buildings. For instance, the Christian Reformed Church in Orange City, Iowa celebrated its fiftieth anniversary in I87I with such a book. ${ }^{27}$

The books also functioned as a published archive, or memory book, for the congregation. Committees and authors included church related photos such as those of current and former consistories and other societies, lists of men who had served as elders and deacons, lists of charter members, and other important details about the history of the church. The more self-aware committees and authors of these books would even mention this intent in their forewords or introductions. Houston, British Columbia's Christian Reformed Church celebrated its twenty-fifth anniversary in I964. Reverend Simon Viss explained that one reason for the publication of the book was that 'a great deal of information is available today which will be lost by the time another twenty five years have past'. ${ }^{28}$ The Editor's Note from the twentyfifth anniversary book in I976 of the Christian Reformed Church in Telkwa, British Columbia, noted that for some, the book would 'be somewhat of a history book-divulging facts and stories about how the church started and how people lived'. ${ }^{29}$ Ray Koning, the author of the fiftieth anniversary of the Chatham, Ontario Christian Reformed Church in 1976 worried that 'much of the story of First church had, prior to this, not been written down' and he was 'concerned that some of the history would be lost and forgotten and covered by the grey cloak of receding time' ${ }^{\circ}$

Authors and committees that compiled these books also recognised the selective nature of the history they were producing. The Christian Reformed Church of Orange City, Iowa celebrated their centennial in I97I. The book's authors acknowledged that 'it is impossible in a history of this scope to encompass all of the activities of the church, or of the individuals who comprise it..$^{\mathrm{I}}$ The authors of the First Christian Reformed Church's centennial book in Pella, Iowa noted in I966 that their chronology was 'very incomplete. In fact, the real work of the church is often ignored because of its personal nature'. ${ }^{2}$ Transcona Christian Reformed Church of Winnipeg, Manitoba celebrated its twenty-fifth anniversary in I978 with a published book. The anniversary com-

27. 'Souvenir', First Christian Reformed Church, Orange City, Iowa (I92I). Available at Heritage Hall.

28. '25th Anniversary', Houston Christian Reformed Church, Houston, British Columbia (I964). Available at Heritage Hall.

29. '25th Anniversary', Telkwa Christian Reformed Church, Telkwa, British Columbia (I976). Available at Heritage Hall.

30. '5oth Anniversary', Chatham Christian Reformed Church, Chatham, Ontario (I976). Available at Heritage Hall.

3I. 'Centennial', First Christian Reformed Church, Orange City, Iowa (I97I). Available at Heritage Hall.

32. 'Centennial', First Christian Reformed Church, Pella, Iowa (I966). Available at Heritage Hall. 
mittee begged its readers to be gracious and recognise the amount of work that went into the book.

There are possibly many more happenings that could have been written down in this "Historical" write up. Many probably say, "this or that should have been in it". But it is very difficult to remember everything and very time consuming to contact people, or to go through records, which wer [sic] not made with the aim of giving for future anniversaries. As a Committee we have tried, many evenings have been spent to gather information and to organize. We hope and pray that what has been written in these pages may be interesting, may bring back the past for you, the reader of this write up. May you feel thankfulness in your hearts and give thanks to the Lord for what HE has done for us in these 25 years. 33

The importance of the books as a collection of information about the church was balanced with the fact that authors and committees were selective in the information presented.

The writers and compilers of the books chose information that would encourage the whole congregation, but particularly the next generation. In forewords, in pastor's messages, and in concluding paragraphs, the point was to encourage the next generation to recognise the importance of the past and be persuaded to continue the church. The Ebenezer Christian Reformed Church in Jarvis, Ontario celebrated its twenty-fifth anniversary in I974. The goal of publishing the book, according to the Foreword by Peter Brouwer, was to summarise the 'record of our church's past and as a means of binding us closer together'.34 The Fruitland Christian Reformed Church in Ontario published its twenty-fifth anniversary book in I975. The authors concluded their narrative history by reminding the readers that the book told 'us the story of His servants, who have faithfully and patiently pointed us to our Father in heaven and the Christian way of life'.35 The 'forward' in the First Christian Reformed Church of Rocky Mountain House, Alberta put it this way, 'May this book be a remembrance to all of us and to our children when we read it. May we understand that the work which our fathers and mothers have done to build the church is Kingdom work. ${ }^{36}$ This was not just a Canadian phe-

33. '25th Anniversary', Transcona Christian Reformed Church, Winnipeg, Manitoba (I978). Available at Heritage Hall.

34. '25th Anniversary', Ebenezer Christian Reformed Church, Jarvis, Ontario (I973). Available at Heritage Hall.

35. '25th Anniversary', Fruitland Christian Reformed Church, Fruitland, Ontario (I975). Available at Heritage Hall.

36. '25th Anniversary', First Christian Reformed Church, Rocky Mountain House, Alberta (I975). Available at Heritage Hall. 
nomenon either. Rev. Walter Akerman wrote in the fortieth anniversary book of Third Christian Reformed Church in Lynden, Washington in I978 that the present and future members should 'count as precious the memory of those who began the church and gave of themselves that God's witness might praise His name. We think of the roll call of the church; we see names that have lost some luster to the present generation but who nevertheless built the church with love and devotion and sacrifice; we note too, names from the roll, parents in the flesh and spirit, and we thank God for our covenant heritage'.37

\section{A common story}

The authors and compilers of these books, when writing to encourage the next generation of the congregation, relied on themes that would resonate with their faith perspective. At least three themes recur throughout the books of the ig6os and ig7os. These themes existed in the books from the United States and Canada, from rural and urban areas, and from old and young settlements. First, the faith perspective that God was in control clearly showed itself. The emphasis on a God who worked in the world through a covenant people shaped the overall narrative. ${ }^{3}$ Second, the authors of the historical narrative stressed the great effort extended by the founders of the congregation to start the church as immigrants. The details might be different from church to church but the dedication of the founders to their church always played a significant role in the narrative. While God controlled things, immigrants still had to work. Finally, the historical narrative noted the progress that had taken place in terms of both building and membership size. These provided easy evidence of God's blessings. These were standard tropes that existed in early books and continued to have currency for the authors in the I960s and I970s reflecting the faith perspective of these Calvinists.

First, the writers of the narrative history of Dutch Reformed congregations acknowledged their reliance on God. Whether it commemorated only 25 years, as in the case of most Christian Reformed churches in Canada in the I970 or commemorating the centennials of nineteenth-century establishment of churches in the United States, this theme demonstrated the role their faith played in interpreting history. In introductions and conclusions, writers noted how God had increased their number and saw fit to bless them. The writer of the twenty-fifth anniversary book of Fruitland, Ontario Christian Reformed Church conveyed this message by saying: 'Christ chooses to build

37. '40th Anniversary', Third Christian Reformed Church, Lynden, Washington (I978). Available at Heritage Hall.

38. Robert Swierenga noted the nature of a covenanted community in his conclusion to Dutch Chicago (Grand Rapids 2002) 745. 
His church.39 The writers of the historical review in the I962 tenth anniversary book of the Terrace, British Columbia Christian Reformed Church emphasised that the book was 'not to show what we have done, but the leading idea in this review is: What God has done for us - and all we as members of the church did, was done by His grace - and so the theme of this evening is applied to this review: Soli Deo Gloria' [emphasis in original]. $4^{\circ}$

Pella, Iowa's Second Christian Reformed Church celebrated 75 years in I972. The opening words of the narrative history echoed this sentiment with the words, 'The Lord hath done great things for us; whereof we are glad'. ${ }^{\text {I }}$ The author of the narrative history in the seventy-fifth anniversary for Hudsonville, Michigan's First Christian Reformed Church emphasised that though 'the people were poor, their number small but with God's help they persevered'. ${ }^{42}$ An often used Bible verse was I Samuel 7:I2 which recounts how Samuel set up a stone and 'named it Ebenezer, saying "Thus far has the Lord helped us" after he defeated the Philistines. According to these books, God had specially blessed these churches.

Introductions and conclusions as well as use of Bible verses in the narrative were only part of the recounting of what God had done. In the messages of pastors to their former parishioners, they stressed the growth of the church as the work of God. Rev. Gerard Bouma noted how 'the Lord has prospered us beyond our wildest imaginations' in his letter in the twenty-fifth anniversary book of London, Ontario Christian Reformed Church in I975.43 Rev. C. Spoor prodded the Christian Reformed Church in New Westminster, British Columbia to 'gratefully observe how God has prospered these efforts'.44 Pastors reminded the congregation of their Calvinist understanding of how God worked in the world.

The decision to migrate was also prompted and controlled by God, according to the story told in commemoration by these Dutch Calvinists. Migration and the subsequent building of institutions was the work of a God who had the whole world in his hands. Authors emphasised this theme to convince the next generation of the need to continue the institutions of their ethnic group

39. '25th Anniversary', Fruitland Christian Reformed Church, Fruitland, Ontario (I975). Available at Heritage Hall.

40. 'Ioth Anniversary', Christian Reformed Church, Terrace, British Columbia (I962). Available at Heritage Hall.

4I. 'Going Forward in Faith', Second Christian Reformed Church, Pella, Iowa (I972). Available at Heritage Hall.

42. '75th Anniversary', First Christian Reformed Church, Hudsonville, Michigan (I977). Available at Heritage Hall.

43. '25th Anniversary', First Christian Reformed Church, London, Ontario (I975). Available at Heritage Hall. Quoted from 'Greetings' by Rev. Gerard Bouma.

44. '25th Anniversary', New Westminster Christian Reformed Church, New Westminster, British Columbia (I977). Available at Heritage Hall. 
because migration and institution building was God ordained. God wanted them to go to North America and wanted them to establish themselves in the institutions of the ethnic group. This interpretation found expression in the I960s and I970s for both the nineteenth and twentieth century immigrants. Celebrating the I25th Anniversary of the founding of the Graafschap Christian Reformed Church near Holland, Michigan, the author observed how the group of I 847 migrants

had sought a strictly Reformed church life with Christian instruction for their children, but because of persecution it was impossible to worship God according to what they believed was required in God's Word. God in His providence had endowed these early pioneers with the desire and the courage to leave their homeland. [...] Each man had been urged to examine himself prayerfully to make sure that material gain was not his chief motive for leaving. 45

The Red Deer Alberta Christian Reformed Church's twenty-fifth anniversary book noted how 'the Lord used this movement [the migration] to build a church in Canada'. ${ }^{6}$ 'These commemorations reminded the faithful that God was in control of their history and this control would continue.

A second theme of these commemorations emphasised the struggle, but eventual success through sacrifice, of those who established the institutions of the Dutch immigrant community. While God was clearly the one who gave the increase, it took the work of the faithful to accomplish the building of institutions. The author of the centennial anniversary book of the First Christian Reformed Church in Pella, Iowa in I966 elaborated.

First Church is very fortunate to possess intact all the minutes and records from the very first meetings in 1866 . These tell a dramatic story of the struggle of our forefathers to establish and maintain this church. It is very difficult for those of us who worship and fellowship in the larger more affluent company of today's congregation to realize how much prayer, how many admonitions, how much sacrifice was required to bring things to where we are today! 47

One pastor drove home the point with recalling how the first offerings received in the church were miniscule but reminded the readers: 'Don't forget, how-

45. 'I25th Anniversary', Graafschap Christian Reformed Church, Holland, Michigan. Available at Heritage Hall.

46. '25th Anniversary', First Christian Reformed Church, Red Deer, Alberta (1976). Available at Heritage Hall.

47. 'Centennial', First Christian Reformed Church, Pella, Iowa (I966). Available at Heritage Hall. 
ever, that these offerings probably involved more sacrifice than a hundredfold more today..$^{8}$

Many authors of the books emphasised how earlier members made the best of the tough situation. The authors pointed out how these early immigrants had relied on and built the church in spite of difficulties. The authors of the Fruitland, Ontario Christian Reformed Church's 25th anniversary book recalled its old, dilapidated building 'with squeaky old chairs which sometimes gave way under the weight, and cobwebs and faded streamers hanging from the ceiling. But we worshipped. Here we found Christian fellowship, and friendships were founded. We soon found that it is not a building that makes a Church. ${ }^{49}$ The books contained comments about the closeness of the congregation in those tough times. The book of the Terrace Christian Reformed Church in British Columbia noted the 'close relationship in those days. The need to come together in society life was greater than it is now perhaps because this was the place where one could speak out.$^{\circ}$ The book of the Riverside Christian Reformed Church, in Wellandport, Ontario, reminded the congregation of the excitement of the early years 'because everyone participated in building something new. Our weekly meetings were often the only times we saw each other and gave us a chance to tell each other about our homes and our work. ${ }^{\mathrm{II}}$ Churches in the United States also emphasised the closeness of the early years in the face of difficulties. The Third Christian Reformed Church of Lynden, Washington wrote a book that highlighted the 'sense of unity and a sacrificial spirit..$^{2}$

Finally, the commemoration books all emphasised the progress the church had made through its shorter or longer history. The churches that survived the test of time memorialised progress and success in their anniversaries. The fact that only congregations that survived commemorate anniversaries and produce books fails to recognise the number of church starts that failed to endure. The successful congregations do not mention the number of failures but assume since they survived that they were specially blessed. The story of progress and success took the form of celebrating the growing number of members and the size and grandeur of the building. Showing that progress in the books took a number of forms. Compilers of the books included photos

48. '25th Anniversary', First Christian Reformed Church, Regina, Saskatchewan (1979). Available at Heritage Hall. Quotation from a letter by Reverend M. Dornbush.

49. '25th Anniversary', Fruitland Christian Reformed Church, Fruitland, Ontario (I975). Available at Heritage Hall.

50. '25th Anniversary', Terrace Christian Reformed Church, Terrace, British Columbia (I977). Available at Heritage Hall.

51. '25th Anniversary', Riverside Christian Reformed Church, Wellandport, Ontario (I977). Available at Heritage Hall.

52. '40th Anniversary, Third Christian Reformed Church, Lynden, Washington (I978). Available at Heritage Hall. 
of successive church buildings as a popular way to show progress. The story behind the photos stressed how the congregation had quickly outgrown its buildings. In Canada, many early congregations rented halls or held services in the afternoon after another congregation that owned the building vacated. The recollections of finally owning their own building fill the pages of the commemoration books.

The authors of these books also highlighted the growth of the church in terms of number of members. The book of the First Christian Reformed Church in Victoria, British Columbia, in 1977 included one such story from the wife of the first pastor. She recalled how 'the faithful few were willing to sacrifice and shoulder responsibilities. Little could we visualize then that twenty five years later there would be a well established church, strong in numbers and witness, in this lovely city of Victoria'. The same book continued the progress theme by noting how the church 'was happy when it could move up a step; first from the YMCA to a real Church; then to its own church which offered two services'.53 A former pastor of Terrace Christian Reformed Church in British Columbia, Rev. John Hanenburg stressed: 'your beginnings were small [...] you faced the challenge, you moved forward in that little rough city in its exquisite mountain setting'. ${ }^{54}$ Many books included tables showing the growth in the number of members with the unacknowledged understanding that migration brought many new faces into their midst.

\section{A story attuned to time and place}

The three themes outlined above demonstrate the commonalities of Dutch Calvinist immigrants and their descendants in the I960s and I970s across the United States and Canada. They reflect how the faith perspective of these Dutch Calvinists with a strong emphasis on God's role in the migration story shaped the broad outlines of how the past would be commemorated and the history told. God was in control but humans had responsibility and God blessed their efforts. However, the particular milieu of the I960s and I970s and the national context showed itself in a number of ways. For instance, many commemorations written in the context of the Cold War emphasised that the reason people had left the Netherlands was for religious freedom. One author boldly asserted, the nineteenth-century immigrants' 'earnest desire and determination to be free to worship God as they believed they should, brought them to America, and kept them here through unimaginable

53. '25th Anniversary', First Christian Reformed Church, Victoria, British Columbia (I977). Available at Heritage Hall.

54. '25th Anniversary', Terrace Christian Reformed Church, Terrace, British Columbia (I977). Available at Heritage Hall. 
difficulties and continued to care for them as they established the church and developed the new community. To Him belongs all the praise!'.55 The Cold War rhetoric of freedom shaped the language of the commemoration to emphasise the United States as a nation of freedom.

The ecclesiastical setting of the I960s and I970s also provided the context for writing these commemoration books. The growth of missionary and evangelical outreach of neo-evangelicals such as Billy Graham influenced these churches as well. Many church anniversary books mentioned the ecumenical Key 73 and the Christian Reformed Church version, Evangelism Thrust. Carl Henry, editor of Christianity Today, organised Key 73 to evangelise all of North America. According to the literature of Key 73, 'The plans call for a gigantic offensive in which every person in North America will be challenged with the claims of Jesus Christ'. ${ }^{6}$ While it fell well short of this lofty goal, it did produce some changes even in the Christian Reformed Church which participated in it through its own Evangelism Thrust.57 The anniversary books of the Christian Reformed Church noted how this influenced their congregations and even how congregations highlighted their mission efforts throughout their histories. For instance, the First Christian Reformed Church in Lynden, Washington emphasised that the effort 'led us to much fruitful self-examination. Training for personal witnessing and visiting was provided'. ${ }^{8}$ The Thunder Bay, Ontario Christian Reformed Church's book in 1975 lamented that 'perhaps through lack of leadership [... its] effort amounted to very little'.59 These churches had been influenced by the evangelicalism they found all around them in the ecclesiastical context.

Even with the commonalities across the border, significant differences did exist between the Dutch immigrants and their descendants in the United States and Canada. Demographically, the Dutch in Canada largely immigrated following the Second Wold War leaving a very different Netherlands than most of the Dutch in the United States who had left in the nineteenth century and early twentieth century. The Netherlands the Canadian contingent left was a pillarised society that few of the nineteenth and early twentieth century immigrants could fully understand. This separated society created different ideals about how the immigrant institutions should interact with the broader society.

55. 'I25th Anniversary', Graafschap Christian Reformed Church, Holland, Michigan (I972). Available at Heritage Hall.

56. Key '73 National Committee, Key '73 congregational resource book (St. Louis I973) II.

57. Earl Schipper, 'Evangelism thrust is human', The Banner, 2I April I972, I4-I7.

58. '75th Anniversary', First Christian Reformed Church, Lynden, Washington (I975). Available at Heritage Hall.

59. '25th Anniversary', First Christian Reformed Church, Thunder Bay, Ontario (I975). Available at Heritage Hall. 
The migration experience clearly shaped the details of the story being told in these books but the experience also influenced the memories of the experiences in the I960s and I970s as well. The closeness to the experience itself obviously formed the basis for the differences. Numerous commemoration books from churches in Canada related personal stories by migrants themselves. These stories provided an intimate look at the migration such as the stories in the book from First Christian Reformed Church in Victoria which included many personal memories. The intimacy of these stories shows how Dutch-Canadians remembered their migration experience through more personal recollections than the Dutch-American versions that relied on church minutes and other written sources.

The authors of the story in the commemoration books in Canada told about a massive migration that caused churches to grow. ${ }^{60}$ The growth of the churches almost completely came from new immigrants. The author of the book for New Westminster Christian Reformed Church in British Columbia wrote that: 'After they had arrived in this country they felt that being here they also had a spiritual and cultural task. ${ }^{6 r}$ Churches survived based on their ability to attract new immigrants to their membership roles. The First Christian Reformed Church in Victoria, British Columbia began their narrative history by noting 'the heavy influx of immigrants from the Netherlands [...]. Many of them were from Reformed background and gradually they swarmed from east to west all over Canada'. ${ }^{62}$ The migration drove the growth of these churches and the anniversary books highlighted that fact.

The role of the church in uniting Dutch-Reformed immigrants from a variety of backgrounds in the Netherlands was also consistently highlighted by authors. Rev. Ralph Boss recalled how they came together in Rehoboth Christian Reformed Church in Toronto, Canada, even though 'they often came from different Reformed churches in the Netherlands, most of them were glad to attend our services, and soon felt at home in our midst. Some who were even fringe-members in the Netherlands became better members here. A few unchurched were led to the Lord'. ${ }^{6}$ According to the story told in the fiftieth anniversary book from 1976 of Chatham, Ontario's Christian Reformed Church, in the I920s 'there were some Baptists, Nederlands Hervormd, etc. For the time being all these different viewpoints and beliefs were

6o. For an overview of the Christian Reformed Church in Canada, see Tymen E. Hofman, The Canadian story of the CRC: its first century (Belleville 2004).

6I. '25th Anniversary', New Westminster Christian Reformed Church, New Westminster, British Columbia (I977). Available at Heritage Hall.

62. '25th Anniversary', First Christian Reformed Church, Victoria, British Columbia (I977). Available at Heritage Hall.

63. '25th Anniversary', Rehoboth Christian Reformed Church, Toronto, Ontario (I978). Available at Heritage Hall. 
held together by a common language and a common need, rather than a common faith or creed. Even those who professed to no religious leanings whatever, found shelter under the wings of the Church. ${ }^{64}$ Rev. H.R. De Bolster noted the 'variety of people! From all over the Netherlands they came. Some men and women from other churches joined the congregation, and a few were added through evangelism outreach' to Maranatha Christian Reformed Church in St. Catharines, Ontario in $1973 .{ }^{65}$ The authors told the story of the church as a unifier of Dutch Protestant immigrants just as there had been pillars in the Netherlands but not rearranged.

Even if almost double the number of migrants went to Canada compared to the United States after the Second World War, Dutch migrants did land in the United States. ${ }^{66}$ Theo Van Halsma recalled in the 1964 centennial book of Holland, Michigan's Central Avenue Christian Reformed Church that 'The Reverend Vander Zwaag was conducting profession classes in both Dutch and English, and the church was growing through the arrival of new families from the Netherlands who emigrated in the post-war years'. ${ }^{67}$ In Lynden, Washington the First Christian Reformed Church's 1975 anniversary book noted: 'Because of the influx of Holland immigrants and the needs of a few of the older generation, Rev. Verbrugge volunteered to conduct a Holland service in addition to two American services, so that each Sunday the congregation worshiped God in two American services supplemented by a Holland service held later in the afternoon. ${ }^{68}$ The books of the churches in the United States stressed how they accommodated the migration.

The authors of some books in Canada emphasised the help they received from their American brothers and sisters. Port Alberni Christian Reformed Church on Vancouver Island, British Columbia, noted how the churches in the United States 'felt that it was their duty to help the new immigrants and they appointed home missionaries and ministers all over Canada'. ${ }^{69}$ Chatham Christian Reformed Church recalled its especially close connection with the Oakdale Park Christian Reformed Church in Grand Rapids, Michigan. The author of the Thunder Bay, Ontario's First Christian Reformed Church anniversary book highlighted the role of the Christian Reformed Church. The

64. '5oth Anniversary', Chatham Christian Reformed Church, Chatham, Ontario (I976). Available at Heritage Hall.

65. '25th Anniversary', Maranatha Christian Reformed Church, St. Catharines, Ontario (I973). Available at Heritage Hall.

66. See the introduction to this special issue.

67. 'Centennial Book, Central Avenue Christian Reformed Church, Holland, Michigan (1964). Available at Heritage Hall.

68. '75th Anniversary', First Christian Reformed Church, Lynden, Washington (I975). Available at Heritage Hall.

69. '25th Anniversary', Port Alberni Christian Reformed Church, Vancouver Island, British Columbia (1976). Available at Heritage Hall. 
author noted, 'much help was received as a church from our fellow Christian Reformed people in the States. Financial help through church building fund and private loans, fieldmen and home missionaries, and used clothes. We remember these things with much appreciation'.70

Even though the Canadian churches remembered their close connection with migration and therefore the Netherlands, churches in the United States in the I96os and I970 also noted their continuing connection with the Netherlands. For instance, Orange City, Iowa's First Christian Reformed Church remembered their connection with the Netherlands after the Second World War. Through their pastor Dr. R. Bronkema and his wife, the church participated in the relief effort 'being among the first to send packages to friends in the Netherlands after the war'. ${ }^{7}$

The proximity to migration was not the only difference between the Dutch ethnics in Canada and the United States. The commemorations of the I960s and I970s also point to differences in the mindset of the Dutch immigrants and their descendants in the United States and Canada toward the broader world, reflecting at least partly changes in the Dutch society they left. The Dutch-Calvinist immigrants in Canada took a more proactive stance toward the Canadian culture. Coming from the pillarised Netherlands and on the coattails of Abraham Kuyper, these post-World War is immigrants wanted to shape the Canadian culture in a more Christian direction. One pastor implored the congregation to become 'loyal Canadians without losing what is best of your Dutch heritage and Reformed world and life view $.7^{2}$ A pastor in Regina, Saskatchewan noted: 'In the past our church has served as a spiritual home for immigrations who found it difficult, due to cultural differences, to feel at home in other churches. This role is virtually finished. [...] We have a more important role to play in this city. This city needs a truly Reformed Church'.73 The Dutch Canadians felt at home in their new homeland relatively quickly and hoped to be role models for their adopted land.

They not only wanted to build churches, but also other institutions that were also commemorated in the I96os and I970s as well. For many in the Christian Reformed Church, starting a parent-run Christian school was a vital endeavour to pass on the faith to the next generation. This was true in both the United States and Canada for many years. The difference was the motiva-

70. '25th Anniversary', First Christian Reformed Church, Thunder Bay, Ontario (I975). Available at Heritage Hall.

7I. 'Centennial', First Christian Reformed Church, Orange City, Iowa (I97I). Available at Heritage Hall.

72. '25th Anniversary', Rocky Mountain House Christian Reformed Church, Rocky Mountain House, Alberta (I975). Available at Heritage Hall.

73. '25th Anniversary', First Christian Reformed Church, Regina, Saskatchewan (1979). Available at Heritage Hall. 
tion for starting them. In the United States, the reasons given in the I960s and I970 for starting the Christian school was a defensive measure against the larger world. The First Christian Reformed Church in Orange City, Iowa noted that the schools started and were sustained because the Christian Reformed Church remains loyal to the tradition of its Dutch forbearers who objected to governmental limitation upon their churches and schools'. ${ }^{74}$ The authors of the Oak Harbor Christian Reformed Church's anniversary books highlighted that the parents there wanted to start a Christian school in I938 to separate from a public school that 'was introducing subjects like dancing into the curriculum'. 75 The defensive reasons given for starting these schools showed how the authors in the I960s and I970s understood the reasons for continuing Christian schools. It is not clear from the sources if the authors of the anniversary books were familiar with the educational developments in the Netherlands. While the founders of the schools may have started their schools knowing about the schoolstrijd in the Netherlands, $7^{6}$ the language of the anniversary books points towards understanding these commemorators as being against the trends they perceived in the government, or public, schools in the ig6os and ig7os.

In Canada, the Dutch remembered starting their Christian schools for slightly different reasons. The First Christian Reformed Church of Vancouver's book had a section named 'Our School' that recounted how the school was started in 1948 with one teacher and eleven students.77 The authors of the anniversary book of the Christian Reformed Church in Smithers, British Columbia, highlighted the debates in 1957 'about what should be first: a new church building or a Christian school'. ${ }^{8}$ The Holland Marsh, Ontario Christian Reformed Church included a section in their book that remembered the 'fact that many of the pioneers in the Holland Marsh were familiar with Christian education in the Netherlands'.79 While the church had only started in I950, by 1951 the Fruitland Christian Reformed Church in Ontario had established a Christian School Society, according to the anniversary book of

74. 'Centennial', First Christian Reformed Church, Orange City, Iowa (I97I). Available at Heritage Hall.

75. '75th Anniversary', Oak Harbor Christian Reformed Church, Oak Harbor, Washington (I977). Available at Heritage Hall.

76. De schoolstrijd was the long and fierce political fight in the Netherlands over the right to set up denominational schools, financed by the state. It started in the nineteenth century and came to a conclusion in I9I7.

77. '5oth Anniversary', First Christian Reformed Church, Vancouver, British Columbia (1976). Available at Heritage Hall.

78. '25th Anniversary', First Christian Reformed Church, Smithers, British Columbia (1976). Available at Heritage Hall.

79. '50th Anniversary', Holland Marsh Christian Reformed Church, Holland Marsh, Ontario (I978). Available at Heritage Hall. 
I975. ${ }^{80}$ The almost immediate start of parent-run Christian schools reminded the readers of books in the I96os and I970s that the schools started out of a dearly held principle brought from the Netherlands where Calvinist churches had strongly advocated for government funding of separate, denominational schools. This precious principle had been established in I9I7 following the schoolstrijd of the late nineteenth and early twentieth centuries. Accustomed to having separate Christian schools, these immigrants worked hard to establish their schools and to remember the sacrifice it took in Canada to continue the principle of separate schools that were to be a positive example.

Separate, parent-run Christian schools were not the only institutions that Dutch Canadians started to influence the broader culture. The anniversary books remembered how they had started labour organisations, farmer associations, and newspapers. The New Westminster Christian Reformed Church in Vancouver had to start Christian institutions such as schools, presses, social action groups, and radio stations, according to their anniversary book because 'they felt $[\ldots]$ they had received a mandate. They had been brought up with the conviction that all of life was to be submitted to the Lord who died for them ${ }^{8}{ }^{8}$ Riverside Christian Reformed Church emphasised not only school but also its support for the Christian Labour Association of Canada and the Christian Farmer's Association. ${ }^{82}$ As Reverend Persenaire recalled about the early founders, 'they were not only interested in the growth of the church but also sought to promote God's kingdom in other areas'. ${ }^{83}$ These kinds of organisations and the proactive stance toward the broader society were in marked contrast to the commemorations in the United States churches that only mention the defensive Christian schools. The emphasis on the church in the United States reflected the much different situation for leaving the Netherlands in the nineteenth century when the patterns of the community were established, as Michael Douma has noted in this volume.

This difference in the stance towards the broader world can be seen in other aspects of the commemorations as well. For instance, the Christian Reformed churches in Canada fondly remembered participating in national events. One such event was the 1967 centennial of the dominion. A Chris-

80. '25th Anniversary', Fruitland, Christian Reformed Church, Fruitland, Ontario (I975). Available at Heritage Hall.

8I. '25th Anniversary', New Westminster Christian Reformed Church, New Westminster, British Columbia (I977). Available at Heritage Hall.

82. See P. Werkman, “Those Dutchmen do have a wild look about them”: the Christian Labour Association of Canada and the Christelijk Nationaal Vakverbond in the Netherlands, I952-1958', in: George Harinck and Hans Krabbendam (eds.), Morsels in the melting pot. The persistence of Dutch immigrant communities in North America (Amsterdam 2006) I95-2II.

83. '25th Anniversary', Riverside Christian Reformed Church, Wellandport, Ontario (I977). Available at Heritage Hall. 
tian school started there in I967 was named Centennial Christian School. ${ }^{84}$ Churches also remember thanking the Canadians for the liberation of the Netherlands. In Wyoming, Ontario, the Christian Reformed Church remembered how the church celebrated the twenty-fifth anniversary of Canada helping to free the Netherlands. A large section in its book detailed how the congregation 'expressed the thanks of the people of Holland for the sacrifice made by Canadian soldiers [and] for welcoming Dutch immigrants to Canada where they have found a new purpose in life'. 85 The Christian Reformed Church in Thunder Bay, Ontario also remembered celebrating the liberation of the Netherlands, reminding themselves that they had sent their choir to Ottawa to participate in a special service. ${ }^{86}$

The story told in these anniversary books about the language transition again points to the stance of the churches towards the broader culture. The authors of books in the United States highlighted how long their churches maintained the use of the Dutch language until pressure grew so great they could no longer maintain the Dutch language. The First Christian Reformed Church of Pella, Iowa, started a 'Hollandsche School' during the summers of I907 and I908 so students could learn Dutch according to the centennial anniversary book. ${ }^{87}$ Orange City, Iowa's First Christian Reformed Church's I97I book said 'though there were still misgivings, the church was coming to realise it was required of God to speak and witness in the language of the country where it was placed' after nearly 90 years of using Dutch. ${ }^{88}$ Oak Harbor, Washington Christian Reformed Church started because at first immigrants, joined United Presbyterian Church but many 'were unable to understand the English Bible language. [...] the urge and desire to organize a church of our own denomination was so strong that soon action was taken'. ${ }^{89}$ First Christian Reformed Church in Lynden, Washington held onto Dutch while two other Christian Reformed churches started in Lynden that used English only.

The story in the Canadian churches emphasised the quick and almost immediate transition to at least using some English. The New Westminster,

84. '25th Anniversary', Terrace Christian Reformed Church, Terrace, British Columbia (I977). Available at Heritage Hall.

85. '25th Anniversary', Wyoming Christian Reformed Church, Wyoming, Ontario (I977). Available at Heritage Hall.

86. '25th Anniversary', First Christian Reformed Church, Thunder Bay, Ontario (I975). Available at Heritage Hall.

87. 'Centennial', First Christian Reformed Church, Orange City, Iowa (I97I). Available at Heritage Hall.

88. 'Centennial', First Christian Reformed Church, Orange City, Iowa (I97I). Available at Heritage Hall.

89. '75th Anniversary', Oak Harbor Christian Reformed Church, Oak Harbor, Washington (I977). Available at Heritage Hall. 
British Columbia's Christian Reformed Church's anniversary book pointed out that the founders' 'conviction that they should be a Canadian church led them early to become an English speaking church'. The church used English within two months of starting. ${ }^{\circ}$ In a long chronology of historical highlights, the authors of the Terrace Christian Reformed Church anniversary book took pains to call attention to every change in the quick transition to English. ${ }^{\text {I }}$ The Wyoming, Ontario Christian Reformed Church's book underscored how it had used English from the beginning of its organisation. $9^{2}$

\section{Conclusion}

Church anniversary books provide one source for looking at how people in the pews constructed their story and not just denominational or national leaders. These books were directed at those within the congregation for their own edification. While it is clear only a few people in each congregation actually wrote the books, they had to work within the parameters of what would be acceptable to their readers. However, this does not mean that the particular author had no leeway as many acknowledged the subjective nature of writing their history.

The stories told by Dutch ethnics in congregations in the I960s and I970s reflected an identity tied to both their faith perspective and their relationship to the migration experience. The Calvinist religion these immigrants took with them stressed the leading of God throughout the migration experience. He was the one who guided the decisions and blessed the immigrants' endeavours. By examining both sides of the border, this study argues that the similarities in the United States and Canada point to the shared faith perspective of Dutch Calvinists within the Christian Reformed Church. The differences point to the proximity to the migration and the differences in the Netherlands that they left. The relationship to the migration experience for those who landed in Canada and the United States varied considerably because of the historical changes in the Netherlands. The context of the I96os and I970 in each country also shaped the story these churches would tell about themselves.

Church commemorations helped to construct an ethnic identity useful for the continuation of the ethnic institutions, particularly the local congregation.

90. '25th Anniversary', New Westminster Christian Reformed Church, New Westminster, British Columbia (I977). Available at Heritage Hall.

9I. '25th Anniversary', Terrace Christian Reformed Church, Terrace, British Columbia (I977). Available at Heritage Hall.

92. '25th Anniversary', Wyoming Christian Reformed Church, Wyoming, Ontario (I977). Available at Heritage Hall. 
Scholars have noted the importance of the local congregations as both social and meaning making institutions. This study shows how the older generation produced commemorations to pass on a loyalty to the institutions of the ethnic community and its shared identity. They constructed an ethnic identity that emphasised loyalty to separate institutions as a key component coming out of a religious understanding that stressed being a covenant people with separate institutions that God had specially blessed. The importance of passing on this loyalty in the local congregation to the next generation whose faithfulness was being tested in the I960s and I970 did not escape the leaders of the commemorations.

Andrew Kuyvenhoven's call to burn the wooden shoes in I980 clearly came as a shock after the decades of carefully constructed stories of congregations within the Christian Reformed Church. These stories emphasised how immigration from the Netherlands and settlement in North America had been blessed and ordained by God. Changing the ethnic identity of an entire denomination made up of congregations with these kinds of stories would not happen with a single magazine cover or editorial. Even with changing demographics within the denomination, for many members of the Christian Reformed Church, a Dutch ethnic identity would continue to play an important role in how they understood their place in the United States and Canada in the late twentieth century.

\section{About the author}

David Zwart is an Assistant Professor of History at Dordt College in Sioux Center, Iowa, U.s.A. He is also a Ph.D. candidate in history at Western Michigan University in Kalamazoo, Michigan, U.s.A. He has been a middle school teacher in California as well.

E-mail: dzwart@dordt.edu. 